\title{
AGRONOMIC PERFORMANCE AND ESTIMATE OF GENETIC VARIABILITY OF UPLAND RICE GENOTYPES ON ACID SOIL OF CROSS RIVER STATE
}

\author{
G. A. IWO AND E. E. OBOK \\ (Received 18, February 2008; Revision Accepted 14, January 2010)
}

\begin{abstract}
Studies on the performance and genetic variability of five upland rice genotypes which included FARO 43, FARO 46, FARO 49 and NERICA-1 was carried out on acid soil of Calabar, Cross River State. FARO 43 was found to give the highest yield of 4.75 t/ha followed by FARO 49 with $4.69 \mathrm{t} / \mathrm{ha}$, indicating that the two genotypes are tolerant to acid soil condition. The genetic variability estimates revealed low values of genotypic coefficient of variability (GCV) and corresponding high values of phenotypic coefficient of variability (PCV) for all the characters investigated with exception of plant height. High heritability $\left(h^{2}\right)$ and high genetic advance (GA) were observed for number of tillers and productive tillers. Number of days to $50 \%$ flowering, number of grains/panicle and rain yield had high heritability $\left(h^{2}\right)$ values with corresponding low genetic advance (GA). These two characteristics are considered as selection indices for further improvement.
\end{abstract}

KEYWORDS: Acid soil, coefficient of variability, genetic advance, genetic variability, upland rice.

\section{INTRODUCTION}

The rice plant has been growing in the wild prior its domestication; today most countries cultivate varieties belonging to the genus, Oryza with well over twenty different species (RRI, 2001). This crop today is central to the lives of billions of people around the globe and it is the most important staple food in the developing world with other cereals like maize and wheat. Nutritionally, rice is a good source of magnesium, thiamine, niacin, phosphorus, vitamin B6, zinc and copper and, it contributes $50-80 \%$ of daily caloric intake (Grist, 1986). Some varieties have iron, potassium and folic acid. The protein content ranges from 6.4 to $8.5 \%$ (Udoh et al., 2005). Apart from the primary (culinary) importance of rice, it has many industrial uses. For example starch, alcoholic beverages, rice wine and flour for the confectionary industry are made from rice.

Phytin and vitamin B production for the pharmaceutical industry and rice oil for the manufacturing of soap and candle, all come from rice (Udo and Ittah, 2006).

In spite of the abundant potentials of rice, its production still faces numerous climatic, edaphic and environmental constraints. Particularly, soil acidity is one of the prevailing conditions in both the rice and swamp rice ecologies in the world today; rice is grown under different conditions and production systems based on water supply and topography (Windmeijer et al., 1994). Though swamp rice cultivation has a primeval Institution, the upland system has gained importance over the decades as reported by Chopra and Prakash (2002).
However, acid soil related problems are more critical to the upland rice system of cultivation and, these greatly affect optimum cultivation (Singh et al). Soil acidity has been associated with high level of soil weathering as reported by Fageria et al. (2004) and WARDA (1999). Tisdale et al. (2003) explain the mechanism of soil acidity to be the resultant of aluminum toxicity. Aluminum toxicity is probably the most important growth limiting factor in many acid soils, particularly with $\mathrm{pH}$ less than 5.0. This also increases the concentration of micronutrients up to toxic levels, thus, interfering with the uptake, transport and of water and nutrients by plants. Sarkarung (1989) reported that yield losses on acid soils could be very high, up to $50 \%$.

In Cross River State, rice is mostly cultivated under hydromorphic condition. Cultivation of rice on upland condition is not common and this might be due to inadequate knowledge of available and adoptable upland rice varieties. The upland varieties required for this ecology have not been adequately studied in the past. Lack of suitable varieties and the effect of soil acidity limit the yield to $1.5-2.0 \mathrm{t} / \mathrm{ha}$. The soils of Calabar, Cross River State, Nigeria are mostly Oxisols and these are typical acid soils (Ibanga, 2002).

Given the potentials of upland rice production that abound in the state, there is a need to identify acid soil tolerant upland rice genotypes for adaptation in this area. Consequently, though liming is a soil management practice for acid soils, but this only decreases aluminum toxicity according to Tisdale et al. (2003). And Okada and Wissuwa (2003.) The use of acid soil tolerant crop species or cultivars would be a complementary solution

G. A. Iwo, Department of Crop Science, University of Calabar. PMB 1115, Calabar, Cross River State.

E. E. Obok, Department of Crop Science, University of Calabar. PMB 1115, Calabar, Cross River State. 
for the improvement of crop production on such soils. According to Iwo et al. (2006), one of the approaches to bring about improvement of crops is to understand the genetic variability of the yield related traits and the agronomic performance.

Therefore, the purpose of this study was to assess the performance of upland rice genotypes on acid soil condition and also to estimate the genetic variability among the evaluated genotypes.

\section{MATERIALS AND METHOD}

The five upland rice genotypes used for the study were obtained from National Cereals Research Institute (NCRI), Badeggi, Niger State, Nigeria. These were grown in May 2006 and August 2007 cropping seasons at the University of Calabar Teaching and Research Farm, Calabar, Cross River State, Nigeria. The representative soil samples of the area were randomly taken at a depth of $15 \mathrm{~cm}$ with a standard core sampler for the determination of the relevant physiochemical soil properties (Table 1). Randomized Complete Block design with three replications was used for the study. Each of the experimental plot measured
$5 \mathrm{~m}$ by $1 \mathrm{~m}$. The inter-row spacing was $0.25 \mathrm{~m}$ and $0.25 \mathrm{~m}$, respectively. The seeds were planted by dibbling. Thinning was done at two weeks after planting; maintaining a maximum of two stands of plant per hill. The first weeding was carried out at three weeks after emergence followed by the first split fertilizer (NPK $15: 15: 15)$ application, at a rate of $100 \mathrm{~kg} / \mathrm{ha}$. The second weeding took place four after weeks the first weeding; followed with the second split of fertilizer (Urea 46\%) application, at the rate of $50 \mathrm{~kg} / \mathrm{ha}$. For each of the characters, five plants were randomly sampled from the inner row of the experimental plots per replication. The means of the three replicates were subjected to Analysis of Variance (ANOVA) according to Gomez and Gomez (1984) and the estimates of genetic variability determined as suggested by Johnson et al. (1955), Hanson et al. (1956) and Singh and Chaudhary (1995).

The characters investigated were: number of days to $50 \%$ flowering, number of tillers at maturity, number of productive tillers, plant height $(\mathrm{cm})$, panicle weight (g), number of grains/pinnacle, grain weight/pinnacle (g), 1000-grain weight (g) grain yield (t/ha). 
Table1: Physico-chemical properties of the soil in the study area

\begin{tabular}{|c|c|c|c|c|c|c|c|c|c|c|c|c|c|c|c|}
\hline $\begin{array}{l}\text { San } \\
d\end{array}$ & Silt & $\begin{array}{l}\text { Cla } \\
\mathrm{y}\end{array}$ & $\begin{array}{l}\text { Textur } \\
\text { al } \\
\text { Class }\end{array}$ & $\begin{array}{l}\mathrm{p} \\
\mathrm{H}\end{array}$ & $\begin{array}{l}\text { Organi } \\
\mathrm{c} \\
\text { Carbo } \\
\mathrm{n}\end{array}$ & $\begin{array}{l}\text { Total } \\
\text { Nitroge } \\
n\end{array}$ & $\begin{array}{l}\text { Available } \\
\text { Phosphor } \\
\text { us }\end{array}$ & $\mathrm{Ca}_{2}^{+}$ & $\mathrm{Mg}_{2}^{+}$ & $\mathrm{K}^{+}$ & $\mathrm{Na}^{+}$ & $\mathrm{H}^{+}$ & $\mathrm{Al}^{+3}$ & $\begin{array}{l}\text { ECE } \\
\text { C }\end{array}$ & BS \\
\hline & $\begin{array}{l}(\% \\
)^{2}\end{array}$ & & & & $(\%)$ & $(\%)$ & (ppm) & \multicolumn{7}{|c|}{$(\mathrm{cmol}(+) / \mathrm{kg})$} & $(\%)$ \\
\hline 81.7 & 6.7 & $\begin{array}{l}11 . \\
6\end{array}$ & SL & $\begin{array}{l}4 . \\
8\end{array}$ & 1.18 & 0.09 & 57.3 & 1.0 & 0.6 & $\begin{array}{l}0.0 \\
8\end{array}$ & $\begin{array}{l}0.0 \\
5\end{array}$ & $\begin{array}{l}4.6 \\
4\end{array}$ & $\begin{array}{l}2.1 \\
6\end{array}$ & 8.53 & $\begin{array}{l}20 . \\
3\end{array}$ \\
\hline
\end{tabular}

SL: Sandy Loam, ECEC: Effective Cation Exchange Capacity, BS: Base Saturation.

\section{RESULTS AND DISCUSSION}

\section{Agronomic performance}

The agronomic performance of the rice genotypes evaluated in field (table 2 ) showed that there was no significant difference ( $p>0.05$ ) in plant height, panicle length, panicle weight grain weight /panicle and 1000 -grain weight for all the genotypes. There was significant difference in the number of days to $50 \%$ flowering, number of tillers at maturity, productive tillers, grains/panicle and grain yield. FARO 43, FARO 49 and NERICA-1 had $50 \%$ flowering at the same period differing significantly (PL.05) from FARO 46, which was an early maturing genotype, and FARO 48, the late maturing genotype. This was in consonance with the findings of Imolehin and Wada (2000). As reported by Kamura (1956), apart from early maturity, tillering ability and productivity in rice are good parameters that do affect grain yield positively. FARO 48 had the highest number of tiller counts and NERICA- 1 has the least of this and productive tillers.

In terms of number of grains /panicle, FARO 43, FARO 48 and FARO 49 were not significantly different from NERICA-1 and
FARO 46 which gave the lowest number of grain panicle (147.83). However, FARO 43 and FARO 49 had the highest number of grains/panicle of 261.83 and 261.00, respectively. The number of grains/panicle has been reported by Honya (1961) to have a positive correlation with grain yield in rice; with some implications for selection of genotypes for increased grain yield.

For grain yield, though an average yield of 3.82 t/ha was obtained for the five investigated genotypes, FARO 43 gave the highest yield of $4.75 \mathrm{t} /$ ha followed by FARO 49, with 4.69 t/ha. The lowest yield was obtained from NERICA-1 (2.56 t/ha) which differed significantly $(p<0.05)$ from the other genotypes. This further conformed to the average yield estimate of $5.30 \mathrm{t} / \mathrm{ha}$ for twenty different upland rice genotypes worked on by Masajo et al (1986).

It has also been ascertained by IRRI (1994), that good morphogical attributes in rice are possible markers for high yield. These attributes: Robust, heavy grains, thick and sturdy stems as well as erect leaves, were observed on FARO 43 and FARO 49. Thus, these two genotypes were considered to be very promising and tolerant to acid soil conditions of Calabar and its environs. 


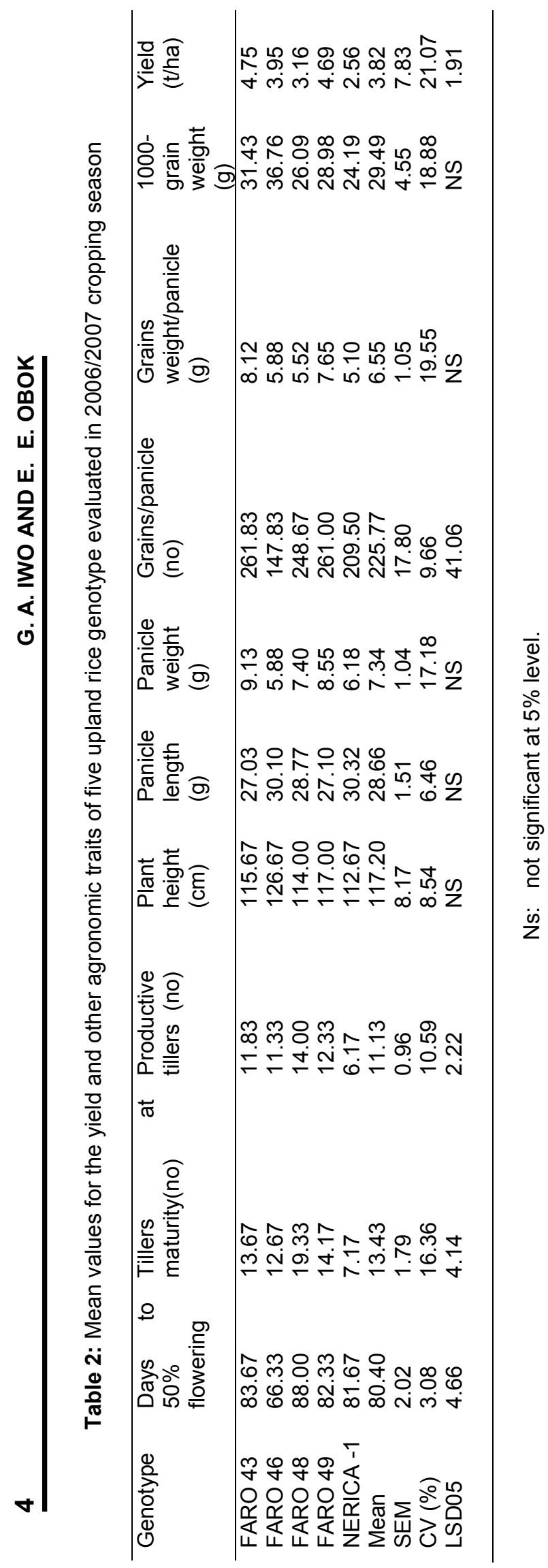




\section{REFERENCES}

Chopra, V. L and Prakash, S.(Eds), 2002. Evolution and adaptation of cereal crops. Science Publishers Inc., USA

Fageria, N.K., Castro, E. M. and Baligar, V. C., 2004. Response of upland rice genotypes to soil acidity $I n$. The red soils of China: Their nature, management and utilization Kluwer Academic publications. Netherlands p. 233-252.

Gomez, K. A. and Gomez, A. A., 1984. Statistical procedures for agricultural research $\left(2^{\text {nd }} E d\right)$. John Wiley and sons Inc., New York, 680pp.

Grist, H.D., 1986. Rice (6 ${ }^{\text {th }}$ Ed). Longman, Singapore.

Hanson, G.H., Robinson, H.F. and Comstock, R. E., 1956. Biometric studies on yield in segregating population of Korean Lespedeza. Agronomy Journal 48:268 -272.

Honya, K., 1961. Studies on the improvement of rice plant cultivation in volcanic ash paddy field in Tohoku district, Tohoku Agricultural experiment station Bulletin 21:1-143.

Ibanga, I. J., 2002. Land resources and environmental management: The Nigeria perspective De-Rio Press Ltd., Calabar, Nigeria.

Imolehin,E. D. and Wada, A. C., 2000. Meeting the rice production and consumption demand of Nigeria with improved technologies. International Rice commission Newsletter.

IRRI, (International Rice Research Institutes), 2001, Rice research and production in the $21^{\text {st }}$ century, IRRI, Manila.

IRRI, 1994. Redesign plant to yield more grain. IRRI Reporter 4 (94). 1-2

Iwo, G. A., Idowu, A. A. and Misari, S. M., 2006. Genetic variability and correlation studies in Sesame (Sesamum indicum L.). Global Journal of Pure and Applied Sciences 13(1): 25-38.

Johnson. W., Robinson, H. F. and Comstock, R. E., 1955. Estimates of genetic and environmental variability in Soyabean. Agronomy Journal 70(1):82-92.

Kamura, A., 1956. Studies on the effect of internal nitrogen concentration of rice plants on constitutional factors of yield. Crop Science Society of Japan 24: 177-180.
Liang, T. and Walter, C. E., 1968. Genetic analysis of development characters in sesame, Madras Agricultural Journal 70(1):82-90.

Masajo, J.M., Alluri, K., Abifarin, A. O. and Janakiran, D., 1986. Breeding for high and stable yields in Africa In Juo, A. S. R. and lowe, J. A. (J. A. (Eds). The wetlands and rice in Sub-Saharan Africa. Proceedings of an international conference on wetland utilization for rice production in SubSaharan Africa, Ibadan 4-8 November, 1985 p. 107-114.

Mehetre, S. S., Qualset, C. O., Baldrrdge, D. E. and Stewart, V. R., 1984. Selection for yield and yield components in wheat, Crop Science Journal 18:795-799.

Mkpufin, N. E., 2006. Field performance and correlation studies of upland rice on acid soil condition. Unpublished B. Agric. Research project. Development of Crop Science University of Calabar, Calabar, Nigeria.

Pathak, H.C. and Dixit, S. K., 1992. Genetic variability and inter relation studies in black seeded Sesame (Sesamum indium L.). Mandras Agricultural Journal 79 (1):94-100.

Sarkanumg, S., 1986. Screening upland rice for aluminum tolerance and blast In Upland rice research. Proceedings of the second International Upland rice conference. IRRI, Manila p. 271-281.

Singn, B.N, Fagada, S., Nkwungwu, M. N., William, C., Jagtap, S. S., Oladimeji, O., Effisue, A. and Okhidievbie, O. 1997. Rice- growing environment and biophysical constraints in different agro-ecological zones of Nigeria Meteorology Journal 2(1):35-44.

Singh, R. K. and Chaudhary, B. D., 1995. Biometric methods in quantitative genetic analysis Kalyani Publishers. New Delhi, p. 39-58

Tisdale, S. L., Nelson, W.L., Beaton, J. D. and Halvin,J. L., 2003, Soil fertility and fertilizers. Pretience Hall of India Private Ltd., New Delhi, 634pp.

Udo, I. A. and Ittah, M. A., 2006. Performance of five swamp rice (Oryza saliva L.) varieties at different sodium chloride levels. Global Journal of Agricultural Sciences 5(2): 117-121.

Udo, D. J., Ndon, B. A., Asuquo, P. E. and Ndaeyo, N. U., 2005. Crop Production techniques for the tropics, Concept Publications Ltd., Lagos. 464 pp. 
Vange, L., Ojo, A. A. and Bello, I. L., 1999. Genetic variability, stability and correlation studies in Lowland rice (Oryza saliva) genotypes. Indian Journal of Agricultural Science 69:30-33.

WARDA, (West Africa Rice Development Association)., 1999. The road to overcoming soil acidity in upland rice, WARDA, Annual report, Bouake.
Windmeijer, P. N.,Duivenboden, N. V. and Andriesse, W. (Eds), 1994. Characterization of rice-growing agroecosystems in West Africa: Semi-detailed characterization of inland valleys in Cote d'Ivoire. Wageningen Agricultural University, Wageningen. 